\title{
BERTAHAN DI TENGAH PANDEMI: DAYA HIDUP KAFE KOMUNITAS TANPA JAMINAN KESELAMATAN
}

\author{
${ }^{1}$ ASMUNI* \\ ${ }^{2}$ ROHIM \\ ${ }^{3}$ HENDRI SUPARTO* \\ ${ }^{1,2}$ Program Studi Ilmu Administrasi Negara \\ ${ }^{3}$ Program Studi Ilmu Administrasi Niaga \\ Sekolah Tinggi Ilmu Administrasi Pembangunan Jember \\ *Email: asmuni.mumun01@gmail.com
}

\begin{abstract}
ABSTRAK
Sebuah kafe komunitas memilih untuk tetap membuka usaha di tengah pandemi. Kafe tersebut bisa disebut sebagai kewirausahaan sosial karena kepemilikan usaha bersifat kolektif dan mempekerjakan karyawan yang berasal dari kelompok marjinal.

Tulisan ini menggunakan pendekatan kualitatif yaitu observasi partisipatoris dan wawancara mendalam terhadap sumber utama untuk menggambarkan alasan kafe komunitas yang tetap membuka usahanya sebagai bentuk survival dari kalangan social enterprenuership. Alasan tetap membuka usaha selama masa pandemi adalah: Pertama, memberdayakan karyawan yang tidak memiliki penghasilan dari usaha lain. Kedua, sebagaimana usaha mikro lainnya, kafe komunitas tersebut, rentan mengalami kebangkrutan karena tidak adanya asuransi usaha. Ketiga, kafe komunitas tersebut harus mempertahankan usaha berdasarkan prinsip rugilaba untuk mencapai surplus penghasilan.

Sesungguhnya, daya hidup kafe komunitas di tengah pandemi tidak memiliki jaminan keselamatan karena mereka hanya menerapkan protokol kesehatan yang sangat minim, seperti penggunaan masker yang tidak memenuhi standar dan fasilitas cuci tangan yang seadanya. Pada level makro, daya survival dari kafe tersebut merupakan sinyal ketidakseriusan stakeholders menjaga keberlangsungan hidup social entrepreneurship di masa pandemi.
\end{abstract}

Kata Kunci: Survival, Kewirusahaan sosial, Pandemi 


\section{PENDAHULUAN}

Tulisan ini membahas sosial entrepreneurs di masa pandemi. Yaitu Fenomena usaha yang mempunyai misi sosial pada satu sisi dan pada sisi lain tetap menjalankan usaha dengan prinsip managemen bisnis murni. Hal tersebut juga untuk membedakan dengan wirasusaha pada umumnya. Menurut (Newth \& Woods, 2014) menjelaskan sosial entrepreneurs merujuk pada tujuan utama untuk penciptaan nilai sosial dan mengejar perubahan sosial. Sehingga dalam menjalankan usaha bisnisnya tidak semata mengejar keuntungan tetapi seberapa besar usaha tersebut berdampak pada nilai-nilai sosial yang diemban.

Selama ini, sosial enterpreneurs dikaitkan dengan alternatif pemberdayaan komunitas yang bertumpuh pada entitas bisnis tertentu untuk membedakan pola pemberdayaan yang dilakukan oleh lembaga swadaya masyarakat (LSM) yang berbasis murni non profit. Sejuah ini lembaga swadaya masyarakat (LSM) digambarkan dengan ideal terutama terhadap tujuan normatifnya. Pendapat Herdiansah (2016) mengambarkan tentang fokus kinerja LSM adalah melakukan perubahan sosial dengan menciptakan kesadaran masyarakat sipil melalui penataan organisasi. Lebih juah, LSM diharapkan dapat mendorong perubahan sosial melalui pemberdayaan komunitas (community empowering), penguatan arus bawah dan peningkatan pendapatan. Namun begitu, LSM memiliki keterbatasan dalam upaya penyelesaian masalah sosial. Hal ini karena ketergantungan LSM terhadap sumber pembiayaan (Firdaus, 2014). Pendapat tentang ketergantungan LSM pada sumber pembiayaan diluar organisasi memunculkan entitas bisnis sebagai bagaian penyelesain permasalahan sosial.

Namun begitu, entitas bisnis juga memiliki kelemahan dalam merespon permasalan sosial. Sebab, respon entitas bisnis lebih sebagai aktivitas sampingan dibandikan urusan utamanya berupa orientasi keuntungan. Seperti disampaikan Yunus (2007) bahwa entitas bisnis 
yang identik dengan sektor swasta memiliki kelemahan dari program corporate social responsibility (CSR). Hanya saja, dalam prakteknya model CSR lebih terlihat sebagai citra perusahaan dibandingkan dengan menyelesaikan misi sosial. Untuk usaha/bisnis dengan skala kecil, memandang visi sosial tereduksi kepada keuntungan pribadi, meskipun juga bisa dimaknai sebagai kemandirian individu yang dekat secara definisi dengan pemberdayaan.

Oleh karena itu, sosial entrepreneurs lebih sebagai model campuran dalam berbisnis. Satu sisi. Beberapa penelitian memperlihatkan gambaran tersebut diantaranya Hahn \& Ince (2016) mengarisbahwahi tujuan bisnis campuran mengacu pada model organisasinya yang bercirikan partisipatori dan penyebaran informasi yang setara. Sementara keluaran model bisnisnya adanya orientasi hasil yang inklusi bagi pemangku kepentingan bisninya. Penelitian ini sejalan dengan penelitian Battilana and Lee (2014) yang mengatakan organisasi hybrid untuk mengejar misi sosial sambil tetap melakukan aktivitas komersialiasi untuk mempertahankan bisnis sebagai dasar sumber pembiayaan.

Atas dasar gap teori tersebut, penelitian ini menjadi penting untuk menghadirkan temuan baru dari eksistensi social entrepreneurs di saat pandami. Argumen dasarnya adalah untuk memperkuat tentang adanya alternatif pemecahan permasalahan sosial seperti kemiskinan dan pengangguran melalui bisnis yang bersifat sosial. Dimana sumber pembiayaan berasal dari kinerja orentasi bisnis bukan berasal dari donator atau lembaga-lembaga donor keuangan. Selanjutnya, penyajian fenomena social entrepreneurs ini juga menggambarkan bahwa aktivis bisnis yang dijalankan rentan terhadap keberlansungannya apalagi ketika pandami terjadi.

Di Indonesia penelitian tentang social entrepreneurs saat pandemi (Covid-19) sudah dilakukan, misalnya Saragih dan Elisabeth (2020) bisnis yang bercorak social enterpreneurs mengimplementasi diversifikasi tidak terkait; penerapan manajemen cash flow; pengaturan 
jam operasional, serta penerapan manajemen persediaan. Dan paling menyakitkan adalah dengan pengurangan karyawan karena penurunan omset mencapai $70 \%$. Bidang usaha bisnisnya adalah pengolahan biji plastik.

Sementara dalam penelitian ini, meskipun mempunyai topik yang sama tentang social entrepreneurs tetapi ada beberapa perbedaan yang mencolok. Pertama, penelitian bidang usaha yang dijalankan adalah produk konsumsi yang dijajakan yaitu kafe. Pangsa pasarnya terintegrasi dengan kerumunan, yang sesungguhnya tabu saat pandemi (Covid-19) untuk menjalankan usahanya. Kedua, katagorisasi bisnis café sebagai social entrepreneurs adalah sebuah anomali. Sebab, secara umum model bisnis dimiliki oleh perorangan dan hubungan kerja dalam menjalankan bisnisnya adalah hubungan majikan-karyawan. Berbeda dengan bisnis kafe yang dalam penelitian ini dikatagorikan sebagai social entrepreneurs, merupakan sebuah kafe komunitas yang menampilkan ciri-ciri yang layak disebut social entrepreneurs.
Penelitian ini selain ingin menjelaskan tentang kafe komunitas sebagai social entrepreneurs, yang dibuktikan dengan kepemilikan usaha bersifat kolektif dan mempekerjakan karyawan yang berasal dari kelompok marjinal. Tujuan lainnya adalah untuk mengambarkan tentang pilihan membuka usaha di saat pandemi sebagai pilihan yang tersedia meskipun mengandung resiko. Pilihan yang tersedia adalah membuka usaha sebagai jalan survival bagi semua stakeholders kafe komunitas ditengah pandemi. Sementara ancaman terinfeksi virus selalu terbuka menimpa semua stakeholders karena minimnya standart protokol kesehatan.

Lokasi penelitian adalah sebuah kafe komunitas di Jember Jawa Timur Indonesia. Selain untuk menggambarkan perilaku usaha produk konsumsi seperti kafe, warung, resto yang tetap buka di hampir semua wilayah saat pandemi. Alasan lain dan utama adalah karena kafe komunitas tersebut sangat dekat dengan kreteria social entrepreneurs. Alasan tambahan, secara metode 
penelitian memungkin peneliti untuk melakukan observasi terutama terkait data-data yang bersifat rahasia seperti data keuangan, akses kepada karyawan atau patner kerja sebagai supplier produk.

$\begin{array}{rcr}\text { Temuan } & \text { penelitian ini } \\ \text { mendapatkan } & \text { survival café }\end{array}$
komunitas sebagai bagian social entrepreneurs untuk keberlangsungan usaha dan stakeholders mereka. Alasan tersebut didasari pada tiga prinsip yang disepakati. Pertama, pemberdayakan karyawan yang tidak memiliki penghasilan dari usaha lain. Kedua, sebagaimana usaha mikro lainnya, kafe komunitas tersebut, rentan mengalami kebangkrutan karena tidak adanya asuransi usaha. Ketiga, kafe komunitas tersebut harus mempertahankan usaha berdasarkan prinsip rugi-laba untuk mencapai surplus penghasilan. Jika tidak dilakukan maka konsekwensinya adalah menutup usaha tersebut. Temuan penelitian ini juga memperlihatkan ironi sebuah survival social entrepreneurs. Pada satu sisi memilih membuka usaha sebagai bagian pertanggungjawaban terhadap nilai-nilai sosial yang diemban. Pada lain sisi mempertaruhkan kesehatan dengan tidak ada jaminan keselamatan.

Penelitian ini membagi tulisan dalam beberapa bagian. Setelah pendahuluan sebagai latarabelakang permasalahan, tulisan ini menjelaskan metode yang digunakan. Lalu pada bagian ketiga menghadirkan landasan teori sebagai pijakan akademik social entrepreneurs. Pada bagian temuan dan diskusi akan membahas survival social entrepreneurs pada saat pandemi sebagai upaya keberlangsungan usaha. Maka pada bagian ini, akan menjawab bebeberapa pertanyaan penting penelitian ini, mengapa café komunitas sebagai bagian social entrepreneurs tetap memilih membuka usahanya? Bagaimana survivalitas café komunitas sebagai bagian social entrepreneurs? Bagaimana café komunitas sebagai bagian social entrepreneurs memandang protokol kesehatan saat pandemi dalam menjalankan usaha mereka? Bagian terakhir kesimpulan yang akan memberikan argumentasi bahwa keberlangsungan usaha itu 
merupakan hal lebih penting daripada protokol kesehatan meskipun stakeholders untuk usaha semacam ini percaya kegiatan tersebut sangat riskan dalam keselematan. Pada level makro, daya

\section{METODE PENELITIAN}

Paradigma penelitian yang digunakan dalam penelitian ini adalah penelitian kualitatif dengan jenis penelitian deskriptif. Definisi metodologi kualitatif adalah "prosedur penelitian yang menghasilkan data deskriptif berupa kata-kata tertulis atau lisan dari orang dan perilaku yang dapat diamati. Pendekatan ini diarahkan pada latar dan individu tersebut secara holistik (utuh). Jadi, penelitian tidak mengisolasikan individu atau organisasi ke dalam variabel atau hipotesis, tetapi perlu memandangnya sebagai bagian dari sesuatu keutuhan". Jenis penelitian yang digunakan adalah penelitian deskriptif. "Tujuan dari penelitian deskriptif ini adalah suatu penelitian yang menggambarkan berupa katakata gambaran dan bukan angkaangka sehingga yang dikumpulkan survival dari kafe tersebut merupakan sinyal ketidakseriusan stakeholders menjaga keberlangsungan hidup social entrepreneurship di masa pandemi.

menjadi kunci terhadap apa yang sudah diteliti (Moleong, 2010).

Penggunaan paradigma kualitatif dengan jenis penelitian deskriptif dalam penelitian ini karena peneliti berusaha mengungkapkan apa adanya mengenai fakta yang ada di lapangan. Data yang dikumpulkan dilakukan dengan wawancara secara mendalam kepada narasumber di sebuah kafe di Kabupaten Jember Jawa timur. Menurut Brinkmann (2013) dalam melakukan wawancara harus berasal dari sumber yang tahu dan terpercaya. Maka dalam penelitian ini narasumber utama yang diwawancarai adalah manager sekaligus pemilik kafe komunitas. Sedangkan narasumber tambahan adalah karyawan terdampak yang dilakukan secara purposive. Datadata sekunder (data keras) diperoleh dari observasi partispasi tidak terikat 
selama dilakukan kerja lapangan. Yaitu kegiatan observasi yang teribat langsung pada kegiatan subjek penelitian (Tedlock,1991) dari proses operasionalisasi kegaitan sampai pada keterlibatan rapat bersama antara pemilik kafe komunitas dengan seluruh karyawan sebagai bagian dari subjek penelitian. Meskipun kegiatan observasi terlibat (partisipatori) tidak lakukan tiap hari tetapi keterlibatan peneliti dilakukan secara berkala.

\section{HASIL PENELITIAN DAN PEMBAHASAN}

Hasil dan diskusi adalah bagian utama dalam penulisan ini, yaitu berupa hasil temuan penelitian dan hal-hal penting yang dibahas dalam penelitian ini. Oleh karena itu, sebelum menginjak pada bagian ini sebagai pendahuluan akan dipaparkan konstruksi teoritik tentang sosial kewirausahaan yang telah berkembang selama ini. Tujuan dialog teori ini untuk mengambarkan pola teori yang menjadi landasan dalam penelitian ini.

Selama ini dunia bisnis selalu dikaitkan dengan bagaimana mencari surplus nilai berupa keuntungan. Namun hal tersebut tidak cukup untuk melihat tatanan yang lebih adil. Bagaimanpun dunia bisnis harus memikirkan lingkungan ekstenalnya. Meskipun dunia bisnis telah beranjak tidak hanya mengumpulkan keuntungan tetapi hal tersebut masih menciptakan kelemahan (Yunus, 2007). Yaitu entitas bisnis yang identik dengan sektor swasta memiliki kelemahan dari program corporate social responsibility (CSR) yang sesungguhnya tidak melibatkan entitas lain diluar mereka untuk memperoleh keuntungan.

Oleh karena itu diperlukan usaha untuk melibatkan lebih banyak lagi kepekaan sosial dari entititas bisnis. Dalam kontesk tersebut, konsep kewirausahan sosial. Newth \& Woods (2014) menjelaskan kewirausahan sosial (social entrepreneurs) merujuk pada tujuan utama untuk penciptaan nilai sosial dan mengejar perubahan sosial yang tidak hanya bersifat kapitalistik saja. Pendapat ini diperkuat Hahn \& Ince (2016) yang mengarisbahwahi bahwa 
adanya misi ganda dalam berbisnis. Tujuan bisnis campuran mengacu pada model organisasnya yang bercirikan partisipatori dan penyebaran informasi pendapatan yang setara.

Corner dan Markus (2010) mengambarkan bahwa penciptaan nilai sosial dari sebuah bisnis atau usaha disebakan adanya aktor yang melihat kebutuhan sosial, serta menjadikan instrumen berbisnis untuk mengatasi persoalan sosial. Semakin banyak aktor bisnis yang memandang mengatasi persoalan sosial itu sebagai kebutuhan sosial akan mendorong peluang mengatasi persoalan sosial menjadi manifestasi.

Pandangan ini sejalan dengan Dey dan Steyaert (2016) etika kewirausahaan sosial biasanya dikonseptualisasikan dalam hubungan dengan properti bawaan atau komitmen moral individu. Dimana unsur-unsur identifikasi kekuasaan, subjektivitas, dan praktik kebebasan menjadi unsur penting dalam memunculkan praktik kewirausahaan sosial.

Sedikit berbeda Dorado dan Ventresca (2013) yang melihat kelembagaan sebagai faktor utama. Kelembagaan yang membingkai kemungkinan keterlibatan kewirausahaan dalam bingkai sosial. Sehingga keterlibatan kewirausahaan sosila dalam konteks masalah sosial yang kompleks, harus ditata fungsionalisi peran aktor kewirausahaan dan tindakan institusional sekaligus. Pendapat yang sama diutarakan Holt dan Macpherson (2010) bahwa hambatan signifikan untuk menciptakan dan mempertahankan usaha sosial adalah kesulitan untuk melegitimasi struktur kelembagaan mereka. Hal ini terutama terjadi pada usaha kecil; Para wirausahawan berjuang untuk menciptakan dan mempertahankan ide-ide baru dan struktur usaha baru yang berbeda lingkungan pasar yang mapan.

Berangkat dari pendapat para ahli tersebut, penelitian ini mencoba menjawab tantangan kewirasuhaan sosial di Indonesia, terutama ketika pandemi terjadi. 


\subsection{Memilih untuk Membuka}

\section{Usaha}

Setelah tiga bulan lockdown. Seiring kebijakan pemerintah melonggarkan aktivitas masyarakat, terutama dibeberapa sektor usaha (https://setneg.go.id rilis resmi presiden Republik Indonesia 18 Mei 2020) mengijinkan beberapa usaha untuk beraktivitas. Meskipun pencabutan tidak sebenarnya dilakukan, beberapa usaha telah melihat pilihan membuka usaha adalah pilihan yang rasional.

Demikian juga dengan café komunitas membuka usaha kembali adalah sebuah pilihan rasional. Pandemi telah memaksa semua usaha bisnis menutup usahanya, termasuk kafe komunitas ini. Fenomena umum di awal-awal pandemi, pemerintah dengan satuan kepolisian mendatangi semua tempat untuk menutup usaha. Bagi kalangan usahawan hal tersebut merupakan pukulan telak. Sebab, tidak memungkinkan untuk bekerja dari rumah seperti kampanye dari pemerintah. Namun begitu, ketentuan untuk menutup usaha diikuti setidaknya dalam tiga bulan awal pandemi. Pilihan yang tersedia hanya berupa layanan take way yaitu layanan produk yang dibawah pulang ke rumah.

Pilihan layanan take way bagi usaha seperti kafe komunitas bukan pilihan strategis. Budaya pelanggan tidak populer dengan cara transaksi model tersebut. Kebanyak pelanggan kafe komunitas memesan produk untuk dinikmati di tempat (cangkrok). Layanan take way ternyata hanya mampu memberi sumbangan penjualan kurang dari $5 \%$ dari total rata-rata omset penjualan sebelum pandemi datang. Pada akhirnya, selama pandemi, usaha seperti kafe komunitas ini bisa disebut menutup usahanya.

Pada sisi lain, pada saat usaha ditutup biaya operasional tetap berjalan baik pemeliharan kantor, lapak usaha dan listrik dan internet. Beban biaya tertinggi adalah honor untuk karyawan tetap dibayarkan seperti biasa. Bagi para pemilik café komunitas ketetapan memberikan hak-hak kepada karyawan didasari bahwa usaha tersebut merupakan milik bersama. Mekispun karyawan bukanlah pemilik modal tetapi 
karyawan adalah modal manusia yang keberadaanya sebagian besar terlibat sejak usaha tersebut didirikan.

Alasan lainnya adalah pemberian hak-hak kepada karyawan disebabkan sebagai upaya pemeliharaan dan pemberdayakan karyawan. Misi awal dari dirikan kafe komunitas ini selain untuk memperoleh keuntungan seperti model bisnis kebanyakan, lebih dari itu untuk memperdayakan kaum marginal. Semua karyawan menjadikan kafe komunitas ini sebagai sumber utama penghasilan. Karyawan café komunitas ini tidak memiliki penghasilan selain dari usaha ini. Secara umum karyawan café berpendidikan rendah dan memasuki awal pernikahan. Berikut profil karyawan:

Tabel.1 Profil Karyawan

\begin{tabular}{ccccc}
\hline Lama bekerja & Jumlah & Pendidikan status & Status & Umur \\
\hline diatas 4 tahun & 4 & lulusan SD dan SMP & 2 menikah & $21-27$ \\
3 -4 tahun & 3 & lulusan SD dan SMP & 2 menikah & $19-27$ \\
2-3 tahun & 2 & lulusan SMA & 1 menikah & $19-27$ \\
1-2 tahun & 2 & lulusan SMA & 1 menikah & $22-24$ \\
\hline
\end{tabular}

Sumber: Observasi pada "My Way Kafé (Kafe Komunitas)

Atas dasar misi sosial dari usaha tersebut maka pada saat usaha berhenti karena pandemi, karyawan tetap memperoleh hak-haknya. Selama itu pula, usaha kafe hanya dijaga secara bergantian tanpa operasionalisasi penjualan. Padahal dalam perhitungan bisnis, kondisi tersebut mengharuskan adanya rasionalisasi karyawan. Namun begitu pilihan mengurangi atau memperhentikan karyawan bukan opsi yang didapat dijalankan oleh pemilik usaha. Alasanya karena semua karyawan menyandarkan pengasilan keluarganya pada usaha kafe komunitas.

Untuk mensiasati penjualan yang berhenti pada satu sisi. Sementara biaya-biaya usaha tetap dikeluarkan maka selama awal pandemi, di level managemen kafe komunitas ini mengalihkan tabungan usaha untuk mensubsidi pengeluraan gaji karyawan. Tabungan usaha yang dimaksud adalah tabungan yang akan 
digunakan untuk membayar sewa tempat usaha atau memelihara kemungkinan kerusakan kafe saat beroperasi.

Kafe komunitas sebagai bagian social entrepreneur, memilih pilihan di atas berdasarkan asumsi bahwa pandemi tidak akan berlangsung lama. Kedua, atas dasar prediksi kemampuan tabungan yang ada. Bahwa model subsidi biaya usaha saat usaha tidak beroperasi ini mempunyai keterbatas waktu. Batas yang disepakati yaitu selama tiga bulan. Setelah tiga bulan operasional penjualan tidak dijalankan maka pilihannya hanya tinggal membuka kembali usaha kafe atau menutup selamanya. Atas dasar ini, maka semua pihak bersepakat untuk membuka usaha kembali dengan resiko yang sesungguhnya minim perlindungan kesehatan.

\subsection{Survival Kafé Komunitas}

Untuk memperlihatkan pola survivalitas pada bagian awal sub bab ini akan diperlihatkan dinamika tren pembukuan keuangan dari café komunitas tersebut. Data ini akan mengambarkan keuntungan usaha saat sebelum pandemi, saat pandemi dan "normal baru". Normal baru merujuk pada istilah yang dipakai saat pandemi, tetapi kegiatan sosialekonomi telah berangsung-angsur berjalan. Jadi, momen terakhir ini merupakan keputusan untuk membuka kembali usaha setelah penutupan wilayah secara terbatas. Berikut gambar perolehan laba usaha kafe komunitas yang dimaksud:

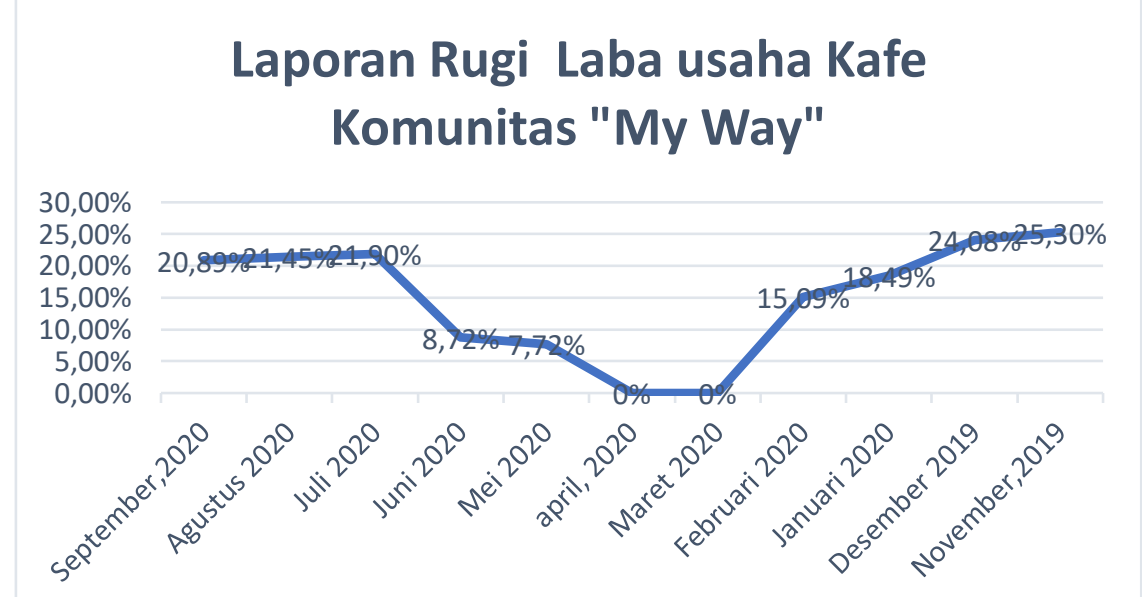

Sumber: Dari Pembukuan Rugi-Laba My way Café (kafé komunitas)

Gambar 1. Perkembangan Laporan Rugi satu tahun terakhir 
Berdasarkan data di atas dapat dilihat bahwa sebelum pandemi datang posisi keuangan café komunitas stabil dengan perbandingan omset terhadap modal usaha mencapi $20-a n \%$. Ini sekaligus mencerminkan tren keuntungan dari usaha tersebut. Namun demikian musim kering datang juga yaitu saat stakeholder dalam hal ini pemerintah membuat keputusan melakukan penutupan untuk hampir semua komuditi kecuali bahan pokok.

Data di atas menjelaskan bahwa kurva terendah terjadi saat pandemi datang yaitu hilangnya keuntungan dari sebuah usaha. Namun demikian tanda-tanda penurunan usaha sudah terlihat sejak kabar pandemi merebak. Sejak januari kecenderungan penurunan omset juga terlihat. Kemudian kecenderungan naik terjadi saat memasuki fase "normal baru".

Pola survivalitas merujuk pada data di atas maka dapat dijelaskan sebagai berikut. Pertama, pada fase awal pandemi, kafe komuitas ini tetap memperkerjakan semua karyawan meskipun lapak penjualan ditutup. Itu berarti semua upaya bertahan diri, biaya usaha diambilkan dari tabungan usaha. Pada fase awal, usaha komunitas lebih menitikberatkan pada tujuan sosialnya. Yaitu semua pihak yang terlibat dalam pengelolaan kafe komunitas tetap memperoleh penghasilan saat ekonomi dunia memasuki depresi.

Kedua, fase konsolidasi. Fase ini adalah fase pengambilan keputusan sejauh mana batas kemampuan keuangan kafe komunitas mampu memberi subsidi kepada karyawan. Sebagai upaya menjaga keberangsungan, pihak manegemen membuat kalkulasi kemampuan biaya subsidi untuk menghindari kebangkrutan.

Ketiga, fase membuka usaha kembali. Kafe komunitas tersebut harus mempertahankan usaha berdasarkan prinsip rugi-laba untuk mencapai surplus penghasilan. Pilihan membuka usaha kembali kafe komunitas ini disebabkan kemampuan keuangan usaha yang telah menghawatirkan. Dan semua pihak sejutu untuk membuka kembali penjualan produk kafe 
tersebut atas nama keberlangsungan usaha.

\subsection{Pandangan pada Protokol Kesehatan}

Pandangan atas protokol kesehatan dibangun atas dasar kesadaran bahwa isu kesehatan penting tetapi membuka usaha tidak kalah penting. Sehinnga yang terjadi adalah kesadaran tersebut tidak menempatkan isu kesehatan sebagai alasan paling dominan atas isu ekonomi. Banyak pelaku usaha yang percaya bahwa pandemi bukanlah sebagai hal yang sungguh mengerikan. Namun begitu, adanya edukasi dari pelaku kesehatan tentang bahaya pandemi berdampak pengetahuan para pelaku usaha tentang munculnya klaster penyebaran pandemi juga menjadi pertimbangan untuk melakukan perlakuan pada cara menjalankan usaha.

Ketika kampanye besar-besaran di awal pandemi untuk bekerja dari rumah atau tidak melakukan pulang kampung saat lebaran, semua pihak termasuk wirausaha sosial menerima sebagai pengorbanan bersama.
Puncaknya adalah ketika terjadi swiping kepada semua pelaku usaha termasuk pada kafe komunitas menerima sebagai bagian partisapasi mengatasi keadaan darurat. Apalagi cara swiping dari aparat keamanan biasanya diiringi dengan liputan media yang luas.

Kondisi tersebut menciptakan traumatik untuk tidak membuka usaha. Meskipun keinginan paling dasar dari pelaku usaha, seperti kafe komunitas ini adalah tetap membuka lapak usahanya secara normal. Namun ketentuan yang larangan untuk membuka usaha memaksa pelaku usaha untuk tunduk kepada ketentuan tersebut.

Dalam perjalanannya, tentu saja dari sudut pandang ekonomi-bisnis, setiap usaha yang ditutup secara "paksa" akan menyebabkan kerugian usaha. Apalagi, tidak semua pelaku usaha memperoleh insentif usaha seperti yang dijanjikan pemerintah. Pada tataran normatif, pemerintah menjanjikan insentif usaha kepada usaha terdampak pandemi. Tetapi dalam pelaksanaannya, tidak semua usaha kecil atau usaha sosial memperoleh insentif usaha. Bahkan, 
jika pun ada usaha kecil atau usaha bisnis yang memperoleh insentif usaha, hal tersebut tidak cukup untuk menutupi biaya operasioanl usaha.

Kafe komunitas ini adalah salah satu usaha kecil dan usaha sosial yang ternyata tidak memperoleh insentif usaha tersebut. Dengan kata lain, banyak pelaku usaha kecil dan usaha sosial ini mengurus dirinya sendiri tanpa merasakan kehadiran pemerintah. Oleh sebab itu, usaha seperti kafe komunitas ini mencari solusi sendiri demi keberlangsungan usahanya. Maka pandemi bukan lagi dianggap penghalang untuk membuka usaha kembali. Faktor lainnya, ketentuan atau protokol kesehatan bagi pelaku usaha tidak dilaksanakan secara konsisten. Ada kesan kuat, pelaksanaan ketentuan atau protokol kesehatan hanya dilakukan secara formalitas. Cirinya adalah tegas saat awal dilaksanakan lalu melemah setelah berjalannya waktu. Ketidakkonsistenan ini menjadi salah satu pemicu bagi pelaku usaha untuk berani membuka usaha kembali.

Pandemi dan penggunaan protokol kesehatan sejatinya telah dilakukan sejak awal pandemi oleh kafe komunitas. Setidaknya ini terlihat dari pemasangan spanduk dan disediakan tempat cuci tangan. Namun demikian, itu tidak cukup sebagai alasan bagi kafe komunitas tersebut untuk tidak ditutup secara paksa oleh aparat keamanan saat awal pandemi. Pada saat era "new normal" datang dan keputusan membuka usaha kembali ditetapkan, pemilik kafe komunitas mensiasiati protokol kesehatan dengan mewajibkan setiap pekerja menggunakan masker, menyediakan cuci tangan dan pelanggan juga diharuskan memakai masker. Fenomena ini umum terjadi pada semua pusat bisnis baik yang bisnis murni atau bisnis yang punya misi sosial. Apalagi hampir semua pusat keramaian sudah dibuka kembali oleh pemerintah, khususnya oleh pemerintah daerah.

Fenomena ini menjelaskan beberapa hal. Pertama, kesadaran kesehatan saat pandemi hanya berada dalam tataran elit saja belum menyentuh semua stakeholder, termasuk pelaku usaha kafe komunitas. Kedua, ketaatan pada 
protokol kesehatan lebih standar protokol kesehatan mencerminkan paksaan dari ditafsirkan secara berbeda-beda oleh pemerintah dibandingakn kesadaran masing-masing orang dan menjadi untuk selamatan kesehatan diri tanggung jawab pribadi bukan sendiri pada saat pandemi. Ketiga, tanggung jawab sosial.

\section{KESIMPULAN}

Keberlangsungan usaha kecil merupakan hal lebih penting daripada protokol kesehatan. Adanya usaha kecil atau usaha sosial yang pernah ditutup pada saat pandemi lebih menunjukkan bentuk kepatuhan dari pelaku usaha kepada otoritas pemerintah. Selanjutnya, fenomena membuka usaha kembali mengambarkan bahwa resiko kesehatan yang mungkin terjadi bukanlah hal yang mendesak. Hal yang yang paling mendesak adalah keberlangsungan usaha tersebut supaya tidak mengalami kebangkrutan. Banyak stakeholders percaya kegiatan usaha semacam ini tersebut sangat riskan dalam keselematan tetapi melakukan larangan berjualan atau membuka usaha bukan lagi opsi rasional,

mengingat tidak ada konpensasi insentif usaha kepada pelaku usaha. Oleh karena itu, pelaku usaha mengambil langka sendiri dalam mencari solusi untuk usahanya.

Pada level makro, daya survival dari kafe tersebut merupakan sinyal ketidakseriusan stakeholders menjaga keberlangsungan hidup social entrepreneurship di masa pandemi. Ada kesan kuat, bahwa pemerintah melakukan pencegahan penyebaran pandemi sebatas formalitas, gugur kewajiban dan sporadis. Dampaknya, pelaku usaha kecil dan usaha sosial semacam kafe kamunitas ini tidak tersentuh kebijakan dalam mencari model usaha saat pandemi. 


\section{DAFTAR PUSTAKA}

Ari Ganjar Herdiansah, Randi. 2016. Peran Organisasi Masyarakat (Ormas) dan Lembaga Swadaya Masyarakat (LSM) dalam Menopang Pembangunan di Indonesia. Jurnal Pemikiran dan Penelitian Sosiologi, Vol. 1, No. 1.

Battilana, J., and M. Lee .2014. Advancing Research on Hybrid Organizing - Insights from the Study of Social Enterprises. The Academy of Management Annuals 8(1), 397-441.

Brinkmann, Svend. 2013. Qualitative Interviewing: Understanding Qualitative Research. Oxford University Press.

Dey, Pascal and Steyaert, Chris. 2016. Rethinking the Space of Ethics in Social Entrepreneurship: Power, Subjectivity, and Practices of Freedom. Journal of Busisness Eric. Volume 133 page 627641. Springer Linkhttps://link.springer.com/ar ticle/10.1007/s10551-0142450-y

Corner, Patricia Doyle dan Ho, Markus. 2010. How Opportunities Develop in Social Enterpreneurship. Enterpreneurship theory and Practice. Sage journals. Volume 34 issue 4 page 635659

https://doi.org/10.1111/j.15406520.2010.00382.x

Dorado, Silvia and Ventresca, Marc J. 2013. Crescive entrepreneurship in complex social problems: Institutional conditions for entrepreneurial engagement. Journal of Business Venturing. Volume 28, Issue 1 page 69-82. Elsevier. https://doi.org/10.1016/j.jbusve nt.2012.02.002

Firdaus, Nur. 2014. Pengetasan Kemiskinan Melalui Pendekatan Kewirausahan Sosial. Jurnal Ekonomi dan Pembangunan Vol 22, No. 1. LIPI https://doi.org/10.14203/JEP.22 $.1 .2014 .69-81$

Hahn, Rudiger \& Ince, Inan. 2016. Constituents and Characteristics of Hybrid Businesses: A Qualitative, Empirical Framework. Journal of Small Business Management, pp. 33-52.

Holt, Robin and Macpherson, Allan. 2010. Sense making, rhetoric and the socially competent entrepreneur. International Small Business Journal: Researching Entrepreneurship. journals sagepub.com. Volume: 28 issue: 1, page(s): 2042https://doi.org/10.1177/0266 242609350822

Moleong, Lexy, J. 2010. Metode Penelitian Kualitatif. Bandung. Remaja Rosdakarya.

Newt, Jamie \& Woods, Christine. 2014. 2014. Resistance to Social Entrepreneurship: How Context Shapes Innovation. Journal of Social Entrepreneurship, Vol. 5, No. 2 , 192-213, http://dx.doi.org/10.1080/1942 0676.2014.889739

Rintan Saragih dan Duma Megaria Elisabeth.

2020. 
Kewirausahaan Sosial Dibalik Pandemi Covid 19; Penelusuran Profile dan Strategi Bertahan. Jurnal Manajemen, Volume 6 Nomor 1.

Tedlock, B.1991. From participant observation to the observation of participation: The emergence of narrative ethnography. Journal of
Anthropological Research, 41, 69-94.

Yunus, M., 2007. Creating a World without Poverty: Social Business and the Future of Capitalism. New York (USA): Perseus Books Group.

https://setneg.go.id/baca/index/presid en_jokowi_belum_ada_kebijak an_pelonggaran_psbb 